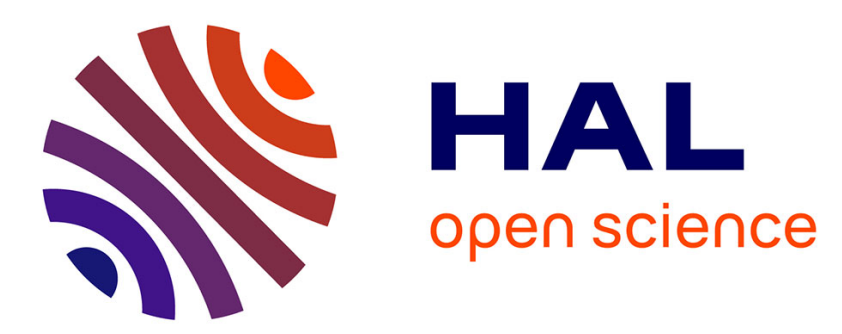

\title{
Words as Environmental Cues: The Effect of the Word "Loving" on Compliance to a Blood Donation Request
} Virginie Charles-Sire, Nicolas Guéguen, Alexandre Pascual, Sébastien Meineri

\section{To cite this version:}

Virginie Charles-Sire, Nicolas Guéguen, Alexandre Pascual, Sébastien Meineri. Words as Environmental Cues: The Effect of the Word "Loving" on Compliance to a Blood Donation Request. Journal of Psychology, 2012, 146 (5), pp.455-470. 10.1080/00223980.2012.654519 . hal-01961056

\section{HAL Id: hal-01961056 \\ https://hal.univ-rennes2.fr/hal-01961056}

Submitted on 19 Dec 2018

HAL is a multi-disciplinary open access archive for the deposit and dissemination of scientific research documents, whether they are published or not. The documents may come from teaching and research institutions in France or abroad, or from public or private research centers.
L'archive ouverte pluridisciplinaire HAL, est destinée au dépôt et à la diffusion de documents scientifiques de niveau recherche, publiés ou non, émanant des établissements d'enseignement et de recherche français ou étrangers, des laboratoires publics ou privés. 


\title{
Interdisciplinary and Applied
}

\section{Words as Environmental Cues: The Effect of the Word "Loving" on Compliance to a Blood Donation Request}

\author{
Virginie Charles-Sire , Nicolas Guéguen , Alexandre Pascual \& Sébastien \\ Meineri
}

To cite this article: Virginie Charles-Sire , Nicolas Guéguen , Alexandre Pascual \& Sébastien Meineri (2012) Words as Environmental Cues: The Effect of the Word "Loving" on Compliance to a Blood Donation Request, The Journal of Psychology, 146:5, 455-470, DOI: 10.1080/00223980.2012.654519

To link to this article: https://doi.org/10.1080/00223980.2012.654519

曲 Published online: 19 Jul 2012.

Submit your article to this journal $₫$

Џلll Article views: 286

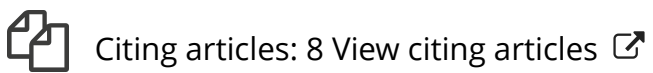




\title{
Words as Environmental Cues: The Effect of the Word "Loving" on Compliance to a Blood Donation Request
}

\author{
VIRGINIE CHARLES-SIRE \\ NICOLAS GUÉGUEN \\ Université de Bretagne-Sud \\ ALEXANDRE PASCUAL \\ Université de Bordeaux 2 \\ SÉBASTIEN MEINERI \\ Université de Bretagne-Sud
}

\begin{abstract}
In a field setting, students $(N=3600)$ on different campus locations were solicited to give blood during a special one-day drive. Solicitations were made through face-to-face interactions. The solicitors wore a white T-shirt with different inscriptions: no inscription, Loving = Helping, Donating = Helping. Results showed that, when compared to the no inscription condition, the number of donors increased when the solicitor-confederates wore the T-shirt Loving = Helping whereas no effect was found when the confederates wore the T-shirt Donating = Helping. The activation spreading theory is used to explain these results. The practical application of these results for blood donation drives and other health-related fundraising events is explored.
\end{abstract}

Keywords: priming, mental representation, loving, blood donation

HEALTH SERVICES DEPEND ON SAFE and readily available supplies of blood to help save lives in many countries. However, the tighter screening of blood donors in recent years has led to a decrease in the volume of blood collected. At the same time, however, the demand for whole blood and blood products is increasing at rates far exceeding the collection rates (Gillespie \& Hillyer, 2002). Unfortunately, there is a worldwide shortage of active blood donors to meet the increased demand for blood (Barkworth, Hibbert, Horne, \& Tagg, 2002). In light

Address correspondence to Nicolas Guéguen, Université de Bretagne-Sud, Rue De La Loi, 56000 Vaness, France; nicolas.gueguen@univ-ubs.fr (e-mail). 
of these circumstances, researching effective methods to increase blood donations has become vital.

To help meet fundraising demands, many techniques have been highlighted in the social psychology literature (see Pratkanis, 2007, for a review). Many of these techniques use sequential requests: the foot-in-the-door technique (Freedman \& Fraser, 1966), the door-in-the-face technique (Cialdini et al., 1975), the low-ball tactic (Cialdini, Cacioppo, Basset, \& Miller, 1978), the lure (Joule, Gouilloux, \& Weber, 1989), and the 1 -in-5 prize tactic (Horvitz \& Pratkanis, 2002). Some of them use ingratiation tactics such as flattery (Dunyon, Gossling, Willden, \& Seiter, 2010), incidental similarity (Burger, Messian, Patel, del Prado, \& Anderson, 2004), or mimicry (Van Baaren, Holland, Kawakami, \& Van Knippenberg , 2004). Others use nonverbal behaviors displayed by the solicitors such as tactile contact (Kleinke, 1977), smiling (Solomon et al., 1981), or gazing (Kleinke, 1980). The goal of the following experiment was to test the effectiveness of a word-priming technique on people's receptivity to a blood donation request.

\section{Priming and Influence Behavior}

Previous research on priming has demonstrated that the activation of a concept or mental representation can exert an influence on subsequent information processing or behavior. Bargh, Chen, and Burrows (1996) found that participants primed with words related to the elderly stereotype (e.g., traditional, retired) walked more slowly when leaving the experiment room than those in the control group; participants primed with the concept of rudeness interrupted the experimenter more quickly and frequently than did participants primed with the concept of politeness. After exposure to sentences describing a stereotyped behavior of dependence (e.g., can't make decisions), participants rated as more dependent a female target who performed the identical behavior as that of a male target. After exposure to sentences describing a stereotyped behavior of aggression (e.g., threatens other people), participants rated a male target as more aggressive than a female target (Banaji, Hardin, \& Rothman, 1993).

Moreover, impression formation was found to be unrelated to the explicit memory of primes. Priming effects can take place when techniques of subliminal priming (i.e., extremely brief exposure to stimuli) are employed. Using this method, Zemack-Rugar, Bettman, and Fitzsimons (2007) showed that individuals subliminally primed with guilt-related adjectives were more helpful than those primed with sadness-related adjectives. Regardless of the duration of exposure to the stimulus, automatic or implicit social cognition occurs when information processing is made without the person's awareness, intention, possibility of control, or effort (Bargh, 1994).

To explain how mental representations can shape social behavior, theorists have hypothesized mental structures consisting of interconnected information or 
attributes. The main assumption is the spreading of activation: the activation of one concept is assumed to spread along a network of meaningfully associated information. Activating the concept of gender, for example, would activate the implicit knowledge structure of gender-linked traits, stereotypes, and norms of behavior.

\section{Surrounding Cues and Behavioral Influence}

Sentences, words, and visual images are environmental cues that can affect the behavior of individuals. Berkowitz and LePage (1967) found that in the presence of a weapon, participants in a laboratory administered more electric shocks to a confederate than without the presence of the weapon. In a restaurant, Jacob, Guéguen, and Boulbry (2011) displayed various figurative cues related to the sea (a boat or the figurine of a sailor, a napkin with a picture of a boat and poetry related to the sea) or not, in the control condition. The study results showed that figurative cues related to the sea increased the patrons' consumption of fish dishes. In a second experiment, they found the same effect with the word fish or fish drawings displayed in several places in the dining room of the restaurant.

Other research studies have shown that pictures present in the immediate environment of an individual affect behavior. Feinberg (1986) showed that in the presence of credit card cues, individuals were more likely to give money to a charitable cause than individuals who were not exposed to the credit card cues. Similarly, McCall and Belmont (1996) found that a tip tray stamped with a credit card insignia led restaurant patrons to leave bigger tips for the waiters or waitresses than when no insignia was primed on the tip tray. Using donation boxes located in various stores, Perrine and Heather (2000) found that responses to a fundraising request to benefit an animal welfare organization increased when color pictures of puppies were displayed on the donation boxes.

From a theoretical perspective, the behavioral consequences of environmental cues are not explained by a priming effect. Marketing scientists have used the stimulus-organism-response (SOR) theoretical model to explain these behavioral effects (Donovan \& Rossiter, 1982; Mehrabian \& Russel, 1974). When a verbal cue is a single word, this word is the stimulus (S) which causes a participant's (or organism's) evaluation (O) followed by some behavioral response (R). Two different evaluations are possible: positive or negative. Consequently, two behavioral responses are activated: approach or avoidance. Approach behaviors are seen as positive responses to someone or to an environment, such as a desire to interact with the person or to explore the environment whereas negative responses include not wanting to interact with the person or to spend time exploring the environment. Therefore, a single word could have the property of activating a positive response, which, in return, will lead the person who is exposed to this word to initiate contact with somebody or to be motivated to perform further behavior. The words love or loving, which represents important concepts in human groupings, could be 
potentially effective words to use for priming or as a cue in people's environment in order to influence their behaviors.

\section{Love and Helping Behavior}

Despite advances in the field of priming, automatic social cognition, or the role of environmental cues on people's behaviors, few attempts have been made to test the influence of an automatic activation of the cognition of love on social behavior. In a natural setting experiment by Lamy, Fischer-Lokou, and Guéguen (2008), participants were interviewed in the street and asked to recall a memory involving love, or, in the control condition, a piece of music they loved. Then, they met another confederate who asked them for money. Results showed that inducing the idea of love had a significant positive effect on compliance to the request for male passersby who were asked for help (giving some money "to take the bus") by a female confederate, but not for female passersby.

These results were confirmed in another study by Fischer-Lokou, Lamy, and Guéguen (2009) in which passersby were asked for directions. Participants induced to recall a memory of love agreed to give directions and spent more time giving directions to the requester than participants in the control condition who were induced to retrieve a piece of music they loved. By using the same methodology for inducing the idea of love versus the idea of music, Lamy, Fischer-Lokou, and Guéguen (2009) observed participants' reactions toward a confederate who inadvertently dropped a stack of compact discs when they were near each other. The results demonstrated that participants were more helpful when they were induced to recall a memory involving love.

In these studies, participants were asked to recall a memory of love that was important to them before their helpfulness was tested. However, research has shown that such behavioral effects can be reached in the absence of any direct reminiscence of love or conscious awareness of love scripts, by means of an automatic activation of the concept of love. In a recent experiment by Lamy, Fischer-Lokou, and Guéguen (2010), male passersby were asked by a female confederate to indicate the direction of Saint Valentine Street or Saint Martin Street in the control group. Thirty meters ahead, the participants then encountered another female confederate who asked for help, pretending a group of four disreputable-looking male confederates had taken her mobile telephone and refused to give it back. Results showed that participants primed with the cognition of Valentine helped the female confederate recover her mobile more frequently than those primed with the cognition of Martin.

The objective of the present experiment was to study the impact of a new but more basic method that induced love cognition and to evaluate its effect on a new dependent variable associated with pro-social behavior. We decided to test the effect of the single presence of the word loving on people's behavior. In the aforementioned studies, possible confounding effects are associated with helping 
behavior. Indeed, in these experiments, it was found that the love inducing variable led men to help a female confederate more readily than a male confederate or that such a love inducing variable was not effective with female participants. It would thus appear that the love inducing method led to further interest for romantic relations more often for men than for women, which, in turn, led only men to help female confederates. When participants were asked to recall a memory of a previous love episode that had occurred in their lives, such a memory could increase the motivation for further romantic relations. In the same way, the word Valentine, which was used as the priming concept in Lamy et al.'s (2010) study, is clearly associated with romantic relationships given the fact that Saint Valentine's Day is an annual commemoration, held on February 14, celebrating love and affection between intimate companions. Both types of priming information are clearly associated with romantic and intimate relationships, but not with general affection toward people.

We thus decided to test the single effect of the word loving, without any other associations, on people's altruistic behavior. Research by Guéguen, Jacob, and Charles-Sire (in press) has shown that altruistic behavior can also be obtained by a single exposition to a physical object related to love. In 12 bakeries, a pink opaque donation box was placed near the cash register with a message soliciting donations for a humanitarian project. The moneybox had a heart shape, a round shape, or a square shape. Results showed that more donations were placed in the moneybox with the heart shape. Guéguen (in press) confirmed this effect in a tipping behavior study. In three restaurants, a bill was placed under a dish that had a heart shape, a round shape, or a square shape. Results showed that more tips were left in the bill dish with the heart shape. The author found that the heart shape had no effect on the evaluation of the employee or on the selfevaluation of the patrons' usual level of altruistic behavior, thus showing that the effect of the heart shape was probably explained by the spreading activation theory only.

\section{Love Prime and Blood Donation}

Given the positive effects of the priming word love on helping requests, we undertook to test the effects of exposition to this love prime on solicited blood donor behavior. Compliance-growth procedures used in previous research failed to increase blood donations. The well-known foot-in-the-door technique (i.e., immediately following small upfront requests with more costly ones) failed, in three experiments, to increase the number of blood donors (Foss \& Dempsey, 1979). The researchers explained this failure by arguing that although the foot-in-thedoor technique is probably effective for minimal forms of aid, it is unlikely to significantly affect willingness to comply with more substantial requests involving behaviors that are psychologically costly to perform, such as blood donation 
requests. Similarly, use of the door-in-the-face technique (i.e., immediately following an initial extreme request with a less costly one) increased verbal compliance with blood donation requests but failed to increase behavioral compliance (Cialdini \& Ascani, 1976). Applying the survey effect technique (Morwitz, Johnson, \& Schmittlein, 1993) on very large samples, Godin, Sheeran, Conner, and Germain (2008) found that previous blood donors who were first asked to complete a mailin questionnaire about donating blood more readily donated 6 months $(+6.4 \%)$ and 12 months $(+6.4 \%)$ later, as opposed to previous blood donors who did not receive the questionnaire.

Thus, given the discrepancies in results obtained between these various compliance-growth procedures, and in light of the positive effect of the loving prime technique on compliance with a broad spectrum of helping behaviors, we decided to test the effect of the loving prime technique with blood donation requests. As the studies mentioned in the previous section had shown that people primed with love show more altruism, we hypothesized that blood donation solicitors wearing the inscription Loving $=$ Helping on their clothes would obtain more compliance to their request.

\section{Method}

\section{Participants}

The study participants were 3,600 students (1,536 males and 2,304 females) who were solicited to donate blood in various areas on the campus of a large university on the West-Atlantic coast in France during a during a one-day blood drive.

\section{Materials}

Our collaborators who solicited students on the campus wore a white, shortsleeved T-shirt. One T-shirt had no inscription; on the second one, Aimer = Aider (Loving = Helping) was written on the front (see Figure 1); on a third T- shirt, the inscription Donner $=$ Aider $($ Donating $=$ Helping $)$ appeared.

\section{Procedure}

Sixteen young female students $(M=20.4$ years, $S D=1.1)$ and 16 young male students $(M=20.6$ years, $S D=1.3)$ were recruited on a voluntary basis in a social psychology course to act as solicitors in the study during the one-day blood drive regularly organized on this campus each year. This blood-collecting event is a typical type of event organized to obtain new donors: most of the students are young and in good health, and it appears that when people give blood for the first time when they are young, the probability that they will become regular donors is increased. Each solicitor wore a t-shirt and the rest of his/her clothing appearance was the same among female and male solicitors: black trousers and a second, black, long-sleeved t-shirt under the white t-shirt. 


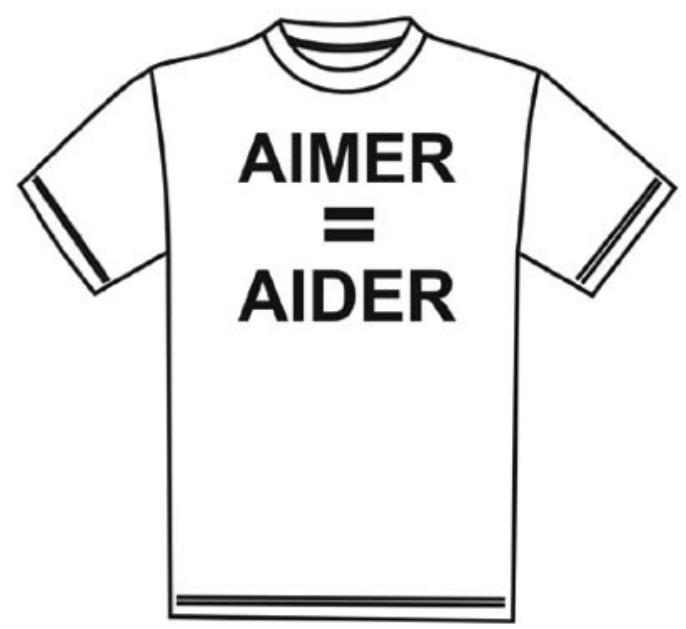

FIGURE 1. Graphical representation of the T-shirt used in the "Loving = Helping" condition.

The experiment was conducted on different campus locations in a large town of more than 300,000 inhabitant near the West Atlantic coast of France. The participants were solicited when entering different areas of the campus: libraries, cafeteria, and School buildings or when walking on the campus. As in previous years, announcements about the blood drive were posted in several places inside and outside the campus buildings.

Each solicitor was instructed to approach a student walking on the campus or entering/leaving one of the locations previously listed by saying the following:

Hello, I have been sent by the blood bank of France to make you aware of our blood drive, which is being conducted today near the cafeteria of the campus, from 10.00 a.m. to 5.30 p.m. Would you like to participate? (the solicitor noted the participant's intent). Please take this card with you (the solicitor offered a business card with information about the blood collection venue and collection hours) and provide it as proof that we have spoken with you. Thanks very much and have a great day.

In order to enable a later determination of which experimental group participants were in, the business cards offered were slightly different. There was a vertical bar on the upper right corner for the control (no inscription) group, the same vertical bar on the upper left corner for the Loving = Helping group, and a vertical bar on the bottom right corner for the Donating = Helping group. Then, later, the medical assistant who greeted potential donors as they entered the blood 
collection room was instructed to ask them whether they had received cards and, if so, to collect the cards from them.

Each solicitor was instructed to test 16 men and 24 women in each experimental condition. Thus, each of the 16 male and 16 female solicitors approached 120 participants (48 men and 72 women). This gender difference results from the fact that in the university where this experiment was carried out, there were 1.5 female students to every male student. The solicitor was instructed to change T-shirts after testing 8 men and 12 women. The order of the T-shirts worn by the solicitor was randomly determined. To prevent possible variations in the solicitors' behavior according to the experimental conditions, the solicitors were not informed of the experimental hypothesis. Earlier, a pre-test had been conducted in the street in order to enable the solicitors to familiarize themselves with the request and to make sure that they acted in the same way in the three experimental conditions.

\section{Results}

The dependent variables used in this experiment were the number of verbal agreements to blood donation requests during solicitor/participant interactions (i.e., verbal compliance, see Table 1) and the number of participants who actually came to the blood collection venue to offer a donation (i.e., behavioral compliance, see Table 2). A 3 (experimental conditions) $\times 2$ (solicitor gender) $\times 2$ (participant gender) Loglinear analysis test was performed with the number of participants who complied with the solicitors' request.

TABLE 1. Number of Participants Having Complied with the Blood Request in the Experimental Conditions According to Gender of the Participant and of the Confederate

\begin{tabular}{llll}
\hline \hline Experimental condition & Male participants & Female participants & Total \\
\hline No inscription & & & \\
Male confederates & $34.7 \%(82 / 236)$ & $43.0 \%(154 / 358)$ & $39.7 \%$ \\
Female confederates & $31.7 \%(79 / 249)$ & $39.4 \%(148 / 376)$ & $36.3 \%$ \\
Total & $33.2 \%$ & $42.5 \%$ & $38.0 \%$ \\
"Loving = Helping" & & & \\
Male confederates & $51.3 \%(117 / 228)$ & $54.7 \%(191 / 349)$ & $53.4 \%$ \\
Female confederates & $49.8 \%(108 / 217)$ & $55.2 \%(207 / 375)$ & $53.2 \%$ \\
Total & $50.6 \%$ & $55.0 \%$ & $53.3 \%$ \\
"Donating = Helping" & & & \\
Male confederates & $40.7 \% \%(98 / 241)$ & $49.1 \%(183 / 373)$ & $45.8 \%$ \\
Female confederates & $42.7 \%(94 / 220)$ & $47.4 \%(171 / 361)$ & $45.6 \%$ \\
Total & $41.6 \%$ & $48.2 \%$ & $45.6 \%$ \\
\end{tabular}


TABLE 2. Number of Participants Having Donated Their Blood in the Experimental Conditions According to Gender of the Participant and of the Confederate

\begin{tabular}{|c|c|c|c|}
\hline Experimental condition & Male participants & Female participants & Total \\
\hline \multicolumn{4}{|c|}{$\begin{array}{l}\text { Part 1: Versus total sample } \\
\text { No inscription }\end{array}$} \\
\hline Male confederates & $10.6 \%(25 / 236)$ & $11.5 \%(41 / 358)$ & $11.1 \%$ \\
\hline Female confederates & $9.2 \%(23 / 249)$ & $11.7 \%(44 / 376)$ & $10.7 \%$ \\
\hline Total & $9.9 \%$ & $11.6 \%$ & $10.9 \%$ \\
\hline \multicolumn{4}{|l|}{ "Loving = Helping" } \\
\hline Male confederates & $15.8 \%(36 / 228)$ & $16.9 \%(59 / 349)$ & $17.1 \%$ \\
\hline Female confederates & $14.7 \%(32 / 217)$ & $13.6 \%(51 / 375)$ & $14.0 \%$ \\
\hline Total & $15.3 \%$ & $15.2 \%$ & $15.2 \%$ \\
\hline \multicolumn{4}{|l|}{ "Donating = Helping" } \\
\hline Male confederates & $11.6 \%(28 / 241)$ & $12.1 \%(45 / 373)$ & $11.9 \%$ \\
\hline Female confederates & $13.2 \%(29 / 220)$ & $11.6 \%(42 / 361)$ & $12.2 \%$ \\
\hline Total & $12.4 \%$ & $11.9 \%$ & $12.1 \%$ \\
\hline \multicolumn{4}{|c|}{$\begin{array}{l}\text { Part 2: Versus verbally compliant participants } \\
\text { No inscription }\end{array}$} \\
\hline Male confederates & $30.5 \%(25 / 82)$ & $26.6 \%(41 / 154)$ & $28.0 \%$ \\
\hline Female confederates & $29.1 \%(23 / 79)$ & $29.7 \%(44 / 148)$ & $29.5 \%$ \\
\hline Total & $29.8 \%$ & $28.1 \%$ & $28.7 \%$ \\
\hline \multicolumn{4}{|l|}{ "Loving = Helping" } \\
\hline Male confederates & $30.8 \%(36 / 117)$ & $30.9 \%(59 / 191)$ & $30.8 \%$ \\
\hline Female confederates & $29.6 \%(32 / 108)$ & $24.6 \%(51 / 207)$ & $26.3 \%$ \\
\hline Total & $30.0 \%$ & $27.6 \%$ & $28.6 \%$ \\
\hline \multicolumn{4}{|l|}{ "Donating = Helping" } \\
\hline Male confederates & $28.6 \%(28 / 98)$ & $24.6 \%(45 / 183)$ & $26.0 \%$ \\
\hline Female confederates & $30.9 \%(29 / 94)$ & $24.6 \%(42 / 171)$ & $26.8 \%$ \\
\hline Total & $29.7 \%$ & $24.6 \%$ & $26.4 \%$ \\
\hline
\end{tabular}

When considering verbal compliance, a main effect of the experimental conditions was found $\left(\chi^{2}(2, N=3583)=56.22, p<.001, r=0.12\right)$. Additional comparisons revealed that the no inscription response condition was statistically different from both the Loving $=$ Helping condition $\left(38.0 \%\right.$ vs. $53.3 \%, \chi^{2}(1, N=$ $2388)=56.42, p<.001, r=.15)$ and the Donating $=$ Helping condition $\left(38.0 \%\right.$ vs. $\left.45.6 \%, \chi^{2}(1, N=2414)=14.74, p<.001, r=.08\right)$. Comparison between the Loving $=$ Helping condition and the Donating $=$ Helping condition was significant $\left(53.3 \%\right.$ vs. $\left.45.6 \%, \chi^{2}(1, N=2364)=14.74, p<.001, r=.08\right)$. A main effect of participant gender was found $\left(\chi^{2}(1, N=3583)=14.64, p<\right.$ $.001, r=0.06)$ revealing that women complied more frequently than men. No significant main effect of solicitor gender was found $\left(\chi^{2}(1, N=3583)=0.64\right.$, 
$p=.42, r=0.01)$. We found no significant interaction between participant gender and/or solicitor gender and experimental conditions $(p>.20)$.

When considering behavioral compliance, a statistical analysis was performed with the total sample of participants solicited and with the subset of those who had verbally complied. The analysis of the number of total participants solicited (Table 2, Part 1). showed a main effect of the experimental conditions $\left(\chi^{2}(2\right.$, $N=3583)=10.58, p=.005, r=0.05)$. Further comparisons revealed that the no inscription response condition was statistically different from the Loving $=$ Helping condition $\left(10.9 \%\right.$ vs. $15.2 \%, \chi^{2}(1, N=2388)=9.31, p=$ $.002, r=.06)$ but not significantly different than the Donating $=$ Helping condition $\left(10.9 \%\right.$ vs. $\left.12.1 \%, \chi^{2}(1, N=2414)=0.88, p=.35, r=.02\right)$. Comparison between the Loving $=$ Helping condition and the Donating $=$ Helping condition was significant $\left(15.2 \%\right.$ vs. $\left.12.1 \%, \chi^{2}(1, N=2364)=4.79, p=.03, r=.04\right)$. Neither a main effect of participant gender $\left(\chi^{2}(1, N=3,583)=0.01, p=.75, r=\right.$ $0.01)$ nor a main effect of solicitor gender $\left(\chi^{2}(1, N=3,583)=0.47, p=.49, r=\right.$ $0.01)$ was found. We found no significant interaction between participant gender and/or solicitor gender and experimental conditions $(p>.20)$.

When considering the analysis of participants who had verbally agreed with the request (Table 2, Part 2), no main effect of the experimental conditions was found $\left(\chi^{2}(2, N=1632)=0.93, p=.63, r=0.02\right)$ and further pairwise comparisons revealed no significant difference $(p>.30)$. Neither a main effect of participant gender $\left(\chi^{2}(1, N=1,632)=1.87, p=.17, r=0.03\right)$ nor a main effect of solicitor gender $\left(\chi^{2}(1, N=1,632)=0.19, p=.66, r=0.01\right)$ was found. We found no significant interaction between participant gender and/or solicitor gender and experimental conditions $(p>.40)$. Overall, these results suggest that the rate of behavioral compliance compared with the number of participants who verbally agreed to donate blood remained the same in the different experimental groups.

\section{Discussion}

Results from this field experiment confirm our initial hypothesis that associating words in an equation (Love = Helping) increased compliance with a blood donation request. First, a higher level of compliance was found when considering the data for verbal and behavioral compliance together. However, when considering only those people who initially consented to give blood (but did not actually donate), the Loving = Helping prime was not associated with higher compliance. Second, we found that the word Loving was linked to increased donations when compared with the control (no word) condition and was more effective than the word Donating. This effect is particularly interesting when considering behavioral compliance with the total number of participants solicited. In this case, it appears that the loving prime increased behavioral compliance compared to the control 
condition and the Donating $=$ Helping condition, whereas the Donating $=$ Helping condition revealed no statistical difference with the control condition. Thus, overall, these results seem to show that the loving prime had a high activation level compared to the other prime.

Such effect confirms previous research results that showed the influence of an automatic activation of the cognition of love on helping behavior (FischerLokou et al., 2009; Lamy et al., 2008, 2009, 2010). In these previous studies, the activation of the love cognition was done by asking participants to think about previous romantic events in their life or through the name of a street (Saint Valentine Street). Results showed each time that the love activation increased the helping behavior only when male participants had the opportunity of offering some help to a female confederate. The love cognition had no effect when considering female participants and/or when a male confederate solicited help. In the present blood donating experiment, we did not find this gender effect. In all the conditions, we found that male and female participants complied in the same way to the blood donation request, whether a male or a female solicitor made the request. This no-gender effect could be explained by the fact that the cognition of love used in this experiment is not associated with romance or romantic relationships, but more probably with support, solidarity, and community relationships.

In France, where this experiment was carried out, blood donors receive no money. Giving blood is purely a type of human solidarity behavior. This could probably explain why the love cognition in our experiment led men and women to react in the same way to the request addressed by our male and female confederates. In the studies of Fischer-Lokou et al. (2009) and Lamy Fischer-Lokou, and Guéguen $(2008,2009,2010)$, the love cognition was probably not related to support, solidarity, and community relationship, but rather to romance, romantic relationships, courtship, or, perhaps, with sex. This could be why only men reacted positively to such a priming effect when a woman asked them for help.

Studies highlighting cultural stereotypes have consistently shown that men are more eager for courtship relations or sexual intercourse than women (Hatfield, 1983; Sadalla, Kenrick, \& Vershure, 1987). Such a variation in male and female behavior could explain why, in the love prime studies previously mentioned, male passersby helped female confederates more readily than female passersby did. The love cognition, in these circumstances, may have increased men's desire for romantic relationships, courtship, or sex, which, in turn, led them to help female confederates. Such cognition was probably not activated in female passersby when help was requested by a male confederate and/or was not appropriated when interacting with a female confederate. In the blood donating experiment, the love prime activated a different type of cognition, one that can be activated in the same way and at the same level with men and women, and that is why the same rate of compliance was found according to participant and/or confederate gender. In 
summary, the love prime was different in the previous set of studies and in this blood donating experiment, which explains the discrepant results found in helping behavior according to participant gender.

However, if the spreading activation explanation is plausible when considering the love prime, it does not explain why no effect was found in the Donating = Helping condition. Two possible explanations of this lack of significance are possible. First, this null effect could be explained by the reactance theory (Brehm \& Brehm, 1981; Wicklund, 1974). This theory assumes that people feel free to do certain things. When this perceived freedom is threatened, people are motivated to restore it. In our experiment, the words Donating $=$ Helping may have been perceived by the participants as a form of order to comply, which may have activated some reactance and led them to consider the request less favorably. In French, donner means "to donate," but the same verb is also used when people want to order someone to do something. Thus, in our experiment, this verb was perhaps interpreted as an order to give, which in turn led the solicited participants to see their freedom of behavior as threatened or restricted. This negative feeling could explain why we found a significant decrease in compliance to the request compared to that in the control condition.

\section{Practical Applicability for Fundraising Professionals}

This experiment has some practical applicability. Increasing the number of blood donations has become urgent (Barkworth et al., 2002), particularly in France where the number of donations per donor has decreased during the last decade (Danic \& Lefrère, 2008). Thus, increasing the number of donors becomes important to compensate for this reduction and to increase number of blood products to treat people. Accordingly, organizations all around the world that are responsible for blood collection might be interested in testing various primes that would activate cognition associated with support, solidarity, and community relationships in their public relations, communications, or marketing campaigns.

The results found in this experiment show that one strategy might be to give the Loving = Helping T-shirt, or a variation thereof, to the thousands of volunteers who offer their time to organize blood collection events. An important increase in the total amount of blood donations could be expected. However, precautions must be taken in the choice of words printed on the T-shirt. In this experiment, we found that Loving was associated with an increase in the rate and the amount of donations whereas the word Donating was not. Testing the word prime on actual behavior beforehand is thus essential. Various pre-tests using an experimental design seem to be a good method to evaluate the efficiency of a prime. This experiment, conducted in a field setting, has demonstrated that simple and low-cost interventions can increase blood donations. A slogan such as Loving = Helping is easy to use in various solicitation situations and media, such as mail, electronic mail, face-to-face interactions, or on a badge worn by solicitors. This 
technique is easy to replicate, easy to use, and easy to adapt to other fundraising solicitations and pro-social requests.

\section{Limitations}

This study has some methodological limitations. In this experiment, we examined only students' compliance to a blood request addressed by a confederate of the same age. Previous studies conducted with the love inducing technique (Fischer-Lokou et al., 2009; Lamy et al., 2008, 2009) showed that this technique remains effective when the participants' age ranges between 20 and 60. However, these studies did not examine blood donation requests, and previous studies found that influence techniques used with blood donation requests are not always associated with an increase in the number of blood donors (Cialdini \& Ascani, 1976; Foss \& Dempsey, 1979).

This study was conducted in France, as were the previous studies that focused on activation of the cognition of love on helping behavior (Fischer-Lokou et al., 2009; Lamy et al., 2008, 2009). The positive effect of the word loving on blood donation might not be generalizable to other countries. Hence, replication in other countries is now necessary. Another limitation is that the Loving $=$ Helping condition might have yielded more donations because the confederates changed their manner of solicitation. However, the confederates were unaware of the hypothesis made, and they had been trained in a pre-test to ensure that they acted in the same way in the three conditions.

\section{Conclusion}

In this study, we have stated that the loving concept acts as a prime that leads to the activation of further concepts associated with compassion, support, or solidarity that, in turn, lead participants to offer blood donations more readily. Such an explanation is congruent with the results of previous studies on priming (Bargh et al., 1996; Zemack-Rugar et al., 2007) which, unfortunately, never tested the word love, or words related to love, as primes. Our explanation, however, remains speculative, given that this study focused on end-behavior only. It appears necessary to test in further experiments whether feelings of compassion, support, or solidarity increase among groups of individuals who are exposed to a love prime.

\section{AUTHOR NOTES}

Virginie Charles-Sire is a doctoral student at the Universite de BretagneSud. Her current research interests are compliance gaining-procedures associated with blood donation. Dr. Nicolas Guéguen (Ph.D.) is a Professor of social behavior at the Université de Bretagne-Sud. His research interests are compliance 
gaining-procedures and nonverbal behavior. Alexandre Pascual is an associate professor of social psychology at the Universite of Bordeaux 2. His research interests are compliance gaining-procedures associated with health and social behaviors. Sébastien Meineri is an associate professor of social psychology at the Université of Bretagne-Sud. His research interests are compliance gainingprocedures associated with ecology and altruism.

\section{REFERENCES}

Banaji, M. R., Hardin, C., \& Rothman, A. J. (1993). Implicit stereotyping in person judgment. Journal of Personality and Social Psychology, 65, 272-281. doi: 10.1037/00223514.65.2.272

Bargh, J. A. (1994). The four horsemen of automaticity: Awareness, intention, efficiency, and control in social cognition. In R. S. Wyer, Jr. \& T. K. Srull (Eds.), Handbook of social cognition (2nd ed., Vol. 1, pp. 1-40). Mahwah, NJ: Erlbaum.

Bargh, J. A., Chen, M., \& Burrows, L. (1996). Automaticity of social behavior: Direct effects of trait construct and stereotype activation on action. Journal of Personality and Social Psychology, 71, 230-244.

Barkworth, L., Hibbert, S., Horne, S., \& Tagg, S. (2002). Giving at risk? Examining perceived risk and blood donation behavior. Journal of Marketing Management, 18, 905-922. doi: 10.1037/0022-3514.71.2.230

Berkowitz, L., \& LePage, A. (1967). Weapons as aggression-eliciting stimuli. Journal of Personality and Social Psychology, 7, 202-207.

Brehm, S. S., \& Brehm, J. W. (1981). Psychological reactance. New York, NY: Academic Press. doi: $10.1037 / \mathrm{h} 0025008$

Burger, J. M., Messian, N., Patel, S., del Prado, A., \& Anderson, C. (2004). What a coincidence! The effects of incidental similarity on compliance. Personality and Social Psychology Bulletin, 30, 35-43. doi: 10.1177/0146167203258838

Cialdini, R., \& Ascani, K. (1976). Test of a concession procedure for inducing verbal, behavioral and further compliance with a request to give blood. Journal of Applied Psychology, 61, 295-300. doi: 10.1037/0021-9010.61.3.295

Cialdini, R. B., Cacioppo, J. T., Basset, R., \& Miller, J. A. (1978). Low-ball procedure for producing compliance: Commitment then cost. Journal of Personality and Social Psychology, 36, 463-476. doi: 10.1145/2207676.2208698

Cialdini, R. B., Vincent, J. E., Lewis, S. K., Catalan, J., Wheeler, D., \& Lee Darby, B. (1975). Reciprocal concessions procedure for inducing compliance: The door-in-the-face technique. Journal of Personality and Social Psychology, 31, 206215. doi: 1975-11600-001

Danic, B., \& Lefrère, J.-J. (2008). De vous à moi, donnez votre sang [From you to me, give you blood]. Paris, France: Medi-Text Editions.

Donovan, R. J., \& Rossiter, J. R. (1982). Store atmosphere: An environmental psychology approach. Journal of Retailing, 58, 35-57. doi: 10.1101/gad.1502407

Dunyon, J., Gossling, V., Willden, S., \& Seiter, J. S. (2010). Compliments and purchasing behavior in telephone sales interactions. Psychological Reports, 106, $27-$ 30. doi: 10.2466/PR0.106.1.27-30

Feinberg, R. A. (1986). Credit cards as spending facilitating stimuli: A conditioning interpretation. Journal of Consumer Research, 13, 348-356. doi: 10.1086/209074

Fischer-Lokou, J., Lamy, L., \& Guéguen, N. (2009). Induced cognitions of love and helpfulness to lost persons. Social Behavior and Personality, 37, 1213-1220. doi: $10.1007 / \mathrm{s} 12144-009-9059-9$ 
Foss, R., \& Dempsey, C. (1979). Blood donation and the foot-in-the-door technique: A limiting case. Journal of Personality \& Social Psychology, 37, 580-590. doi: 10.1037/00223514.37.4.580

Freedman, J. L., \& Fraser, S. C. (1966). Compliance without pressure: The foot-inthe-door technique. Journal of Personality and Social Psychology, 4, 195-202. doi: $10.1037 / \mathrm{h} 0023552$

Gillespie, T. W., \& Hillyer, C. D. (2002). Blood donors and factors impacting the blood donation decision. Transfusion Medicine Reviews, 16, 115-130. doi: 10.1053/tmrv.2002.31461

Godin, G., Sheeran, P., Conner, M., \& Germain, M. (2008). Asking questions changes behavior: Mere measurement effects on frequency of blood donation. Health Psychology, 27, 179-184. doi: 10.1037/0278-6133.27.2.179

Guéguen, N. (in press). Helping with all your heart: The effect of cardioid dishes on tipping behavior. Journal of Applied Social Psychology.

Guéguen, N., Jacob, C., \& Charles-Sire, V. (2011). Helping with all your heart: The effect of cardioid cues on compliance with a humanitarian aid request. Social Marketing Quarterly, 17, 2-11.

Hatfield, E. (1983). What do women want from love and sex? In E. R. Allgeier \& N. B. McComick (Eds.), Changing boundaries (pp. 103-134). Palo Alto, CA: Mayfield.

Horvitz, T., \& Pratkanis, A. R. (2002). A laboratory demonstration of the fraudulent telemarketers' 1-in-5 prize tactic. Journal of Applied Social Psychology, 31, 310317. doi: 10.1111/j.1559-1816.2002.tb00217.x

Jacob, C., Guéguen, N., \& Boulbry, G. (2011). Presence of various figurines on a restaurant table and consumer choice: Evidence for an associative link. Journal of Foodservice Business Research, 14, 47-52. doi: 10.1080/15378020.2011.548221

Joule, R.-V., Gouilloux, F., \& Weber, F. (1989). The lure: A new compliance procedure. The Journal of Social Psychology, 129, 741-749. doi: 10.1080/00224545.1989.9712082

Kleinke, C. (1977). Compliance to requests made by gazing and touching experimenters in field settings. Journal of Experimental Social Psychology, 13, 218-223. doi: 10.1016/0022-1031(77)90044-0

Kleinke, C. (1980). Interaction between gaze and legitimacy of request on compliance in a field setting. Journal of Nonverbal Behavior, 5, 3-12. doi: 10.1007/BF00987050

Lamy, L., Fischer-Lokou, J., \& Guéguen, N. (2008). Semantically induced memories of love and helping behavior. Psychological Reports, 102, 418-424. doi: 10.2466/pr0.102.2.418424

Lamy, L., Fischer-Lokou, J., \& Guéguen, N. (2009). Induced reminiscence of love and chivalrous helping. Current Psychology, 28(3), 202-209. doi: 10.1007/s12144-0099059-9

Lamy, L., Fischer-Lokou, J., \& Guéguen, N. (2010) Valentine Street promotes chivalrous helping. Swiss Journal of Psychology, 69, 169-172. doi: 10.1024/1421-0185/a000019

McCall, M., \& Belmont, H. (1996). Credit card insignia and restaurant tipping: Evidence for an associative link. Journal of Applied Psychology, 81, 609-613. doi: 10.1037/00219010.81.5.609

Mehrabian, A., \& Russell, J. A. (1974). An approach to environmental psychology. Cambridge, MA: MIT Press.

Morwitz,V. G., Johnson, E., \& Schmittlein, D. (1993). Does measuring intent change behavior? Journal of Consumer Research, 20, 46-61. doi: 10.1086/209332

Perrine, R. M., \& Heather, S. (2000). Effects of picture and even-a-penny-will-help appeals on anonymous donations to charity. Psychological Reports, 86, 551-559.

Pratkanis, A. R. (2007). The science of social influence. New York, NY: Psychological Press. 
Sadalla, E. K., Kenrick, D. T., \& Vershure, B. (1987). Dominance and heterosexual attraction. Journal of Personality and Social Psychology, 52, 730-738. doi: 10.1037/00223514.52.4.730

Solomon, H., Zener-Solomon, L., Arnone, M., Maur, B., Reda, R., \& Roth, E. (1981). Anonymity and helping. The Journal of Social Psychology, 113, 37-43. doi: 10.1080/00224545.1981.9924347

Van Baaren, R. B., Holland, R. W., Kawakami, K., \& Van Knippenberg, A. (2004). Mimicry and prosocial behaviour. Psychological Science, 14,71-74. doi:10.1111/j.14679280.2005.01619.x

Wicklund, R. A. (1974). Freedom and reactance. Oxford, England: Lawrence Erlbaum.

Zemack-Rugar, Y., Bettman, J. R., \& Fitzsimons, G. J. (2007). The effects of nonconsciously priming emotion concepts on behavior. Journal of Personality and Social Psychology, 93, 927-939. doi: 10.1037/0022-3514.93.6.927

Original manuscript received August 18, 2011

Final version accepted December 26, 2011 